\title{
Determining the Effective Role of Chapattis Prepared from Composite Flour Against Lipid Profile of Experimental Subjects
}

\author{
Muhammad Hanif Mughal* \\ Homeopathic clinic, Islamabad, Pakistan \\ *Corresponding author: Muhammad Hanif Mughal, Homeopathic clinic, Islamabad, Pakistan
}

\section{ARTICLE INFO}

Received: 陆 June 21, 2019

Published: 㗀 June 27, 2019

Citation: Muhammad Hanif Mughal. Determining the Effective Role of Chapattis Prepared from Composite Flour Against Lipid Profile of Experimental Subjects. Biomed J Sci \& Tech Res 19(2)2019. BJSTR. MS.ID.003265.

Abbreviations: ANF: Anti-Nutritional Factors; LDL-C: Low-Density Lipoprotein; HDL: High Density Lipoprotein; LPL: Lipoprotein Lipase; LPL: Lipoprotein Lipase

\begin{abstract}
The current study was used to examine and assess the role of prepared chapattis against lipid profile of human subjects. Considering lipid profile of subjects, mean values of low density lipoprotein, high density lipoprotein, triglycerides, and total cholesterol in normal subjects were $105.65 \pm 6.55,38.35 \pm 2.31,116.79 \pm 7.66$ and $165.75 \pm 10.43$ $\mathrm{mg} / \mathrm{dL}$ in comparison with subjects (consumed chapattis) $98.94 \pm 8.17,43.16 \pm 2.64$, $111.03 \pm 10.71$ and $146.34 \pm 15.1 \mathrm{mg} / \mathrm{dL}$ accordingly. Similarly, low density lipoprotein concentrations (normal subjects) were enhanced from 103.21 \pm 6.39 ( 0 days) to $106.53 \pm 6.59$ (30 days) $\mathrm{mg} / \mathrm{dL}$ in N0 whereas consumption of selected composite flour chapatti group (N1) significantly lowered the LDL level from $104.33 \pm 6.46$ to $91.33 \pm 5.65$ $\mathrm{mg} / \mathrm{dL}$ in same intervals. Moreover, values for high density lipoprotein levels were recorded as $38.70 \pm 2.40,38.35 \pm 2.38,38.00 \pm 2.36 \mathrm{mg} / \mathrm{dL}$ on 0,15 and 30 days intervals respectively in normal subjects of control group whilst consumption of selected composite flour chapatti group (N1) exhibited significant increment in high density lipoprotein concentrations from $42.95 \pm 2.66$ to $43.90 \pm 2.72 \mathrm{mg} / \mathrm{dL}$. Conclusively, it was found that prepared chapattis from composite flour have been found effective against lipid profile of human subjects.
\end{abstract}

Keywords: Cereals; Composite Flour; Chapatti; Lipid Profile

\section{Introduction}

Cereals belong to the family Gramineae and grown for their highly nutritious edible part or grain and frequently referred as grains [1]. Cereals have been consumed directly as staple foods and indirectly as feed for livestock long ago. They are considered as important food sources [2] and foods made of cereals are supposed to be a primary energy source, vitamin B and protein, minerals for the population globally. These crops are grown throughout the temperate and tropical regions of the world and full fil the approximately fifty percent food energy requirements of population. Cereals in form of wheat, rice, maize, barley are significant source of minerals and bioactive compounds to dire human requirements [3]. Among cereals, wheat (Triticum aestivum) belongs to family gramineae and is considered second only to rice as the main human food crop [4]. In terms of nutrition, there are multiple research data which indicate the consumption of fiber-based foods are significantly associated with reduction in prevalence of chronic diseases such as metabolic syndrome, cardiovascular complications, obesity, different types of cancers, and diabetes. Combination of different nutrients in wheat flour imparts multiple health perspectives. Several studies indicate that consumption of dietary fibers reduced the weight gain and obesity incidence whereas fiber utilization is also enhanced the satiety and lowered the energy intake [5]. Barley (Hordeum vulgare L.) prevents from cardiovascular disorder via decreasing the cholesterol concentrations and improving the glucose tolerance [6]. The higher level of cholesterol, triglycerides, very low-density lipoprotein, free fatty acids, and decline level of high-density lipoprotein are linked with hyperlipidemia. Barley $\beta$ glucan has effect on LDL cholesterol, total cholesterol, triglycerides, and high-density lipoprotein (HDL) cholesterol [7]. Mechanistically, barley flour markedly lowers the bile acids absorption, eliminates steroids, increases catabolism of cholesterol, reduces lipoprotein cholesterol secretion, enhances secretion of bile acids, and reduces 
the total body pool of cholesterol [8]. The chickpea (Cicer Arietinum $L$.) is cultivated in different regions of the world as important grain legume crop.

Moreover, dietary fiber in chickpea significantly lowers the cholesterol level and also contains a variety of anti-nutritional factors (ANF) including amylase and protease inhibitors. Diabetes is a chronic global disease burden affecting a large segment of population, worldwide. Various mechanisms have been involved in the progression of this human syndrome, such as pancreatic $\beta$-cell dysfunction, higher concentrations of free fatty acids, insulin resistance, leading to overproduction of reactive oxygen species, as well as pancreatic $\beta$-cell deficiency and apoptosis. The diabetes is promoted the cardiovascular disease which is linked with hyperglycemia, obesity, dyslipidemia, glucose intolerance, and hypertension [9]. Chickpea exhibit hypocholesterolemic effect through multiple mechanisms such as suppression of cholesterol and fatty acid synthesis, reduction of low-density lipoprotein (LDL-C) levels, triglycerides, enhancement in high density lipoprotein, and inhibition of intestinal absorption of cholesterol [10]. The administration of wheat bran in diabetic volunteers caused momentous reduction in serum glycosylated protein levels, lipoprotein cholesterol, glycosylated albumin levels, and serum lipids levels as well as also decreased the concentrations of blood glucose [11].

\section{Material and Methods}

\section{Procurement of Raw Materials}

For research purpose, three types of whole grains (Wheat, Barley, Chickpea) were procured from local market, Faisalabad and then were sifted and cleaned to remove dust, dirt, stalks, and any other undesired materials. The cleaned grains were prepared composite flour to make chapattis (weighed 100 $\pm 2 \mathrm{~g}$ ). Different types of chapattis were prepared from composite flour by using the different concentrations of cereal grains. On the basis of overall acceptability, glycemic index and glycemic load, T3 was used for further analysis.

\section{Selection Criteria}

Normal and hyperglycemic individuals with renal failure and other serious dysfunctions of any major organ were not included in the study.

\section{Bio-Efficacy Studies}

In bio-efficacy trials, two parallel studies i.e. normal (study 1) and hyperglycemic (study 2) were conducted each comprising of two groups as described in Tables 1 \& 3. Each group comprised of 10 subjects. The human efficacy trial continued for thirty days and blood samples of the participants were collected for biochemical assays at fortnightly basis.
Table 1: Bio-Efficacy Plan.

\begin{tabular}{|c|c|c|}
\hline Studies & Groups & Treatment \\
\hline \multirow{2}{*}{$\begin{array}{c}\text { Normal subjects } \\
\text { (Study 1) }\end{array}$} & $\mathrm{N}_{0}$ & Control \\
\cline { 2 - 3 } & $\mathrm{N}_{1}$ & $\begin{array}{c}\text { Consuming selected composite } \\
\text { flour chapatti }\end{array}$ \\
\hline $\begin{array}{c}\text { Hyperglycemic } \\
\text { subjects (Study 2) }\end{array}$ & $\mathrm{H}_{0}$ & Control \\
\cline { 2 - 3 } & $\mathrm{H}_{1}$ & $\begin{array}{c}\text { Consuming selected composite } \\
\text { flour chapatti }\end{array}$ \\
\hline
\end{tabular}

\section{Biochemical Analysis}

Lipid Profiles: For the evaluation of lipid profile, levels of low-density lipoprotein, high density Lipoprotein, triglyceride and cholesterol were measured.

Low Density Lipoproteins: Low density lipoproteins in human serum samples were determined by adopting the procedure of Kim et al. [12] (Table 2).

High Density Lipoproteins: High density Lipoprotein (HDL) level was measured by Cholesterols Precipitant Methods as described by Alshatwi et al. [13]

Triglyceride: Triglycerides levels were checked by (GPO-PAP) methods [12].

Cholesterol: Cholesterol levels were measured using CHODPAP method as mentioned by Kim et al. [12].

\section{Statistical Analysis}

All data regarding end parameters were assessed using ANOVA. To check the level of significance, two factors factorial under completely randomized design was used. For post hoc comparison, least significant difference test was performed [14].

\section{Results}

(Table 2) represents the treatment effect in both studies. Pooled means for low density lipoproteins, high density lipoproteins, triglycerides and total cholesterol in normal individuals who did not consumed the composite flour chapatti were $105.65 \pm 6.55$, $38.35 \pm 2.31,116.79 \pm 7.66$ and $165.75 \pm 10.43 \mathrm{mg} / \mathrm{dL}$ respectively. While the pooled means of all respective parameters for lipid profile in normal individuals consuming the treatment were observed as $98.94 \pm 8.17,43.16 \pm 2.64,111.03 \pm 10.71$ and $146.34 \pm 15.1 \mathrm{mg} /$ $\mathrm{dL}$ accordingly. In hyperglycemic individuals not consuming the treatment, the pooled means for respective lipid profile parameters were observed as $134.51 \pm 5.08,41.27 \pm 2.20,153.47 \pm 6.2$ and $178.74 \pm 10.33 \mathrm{mg} / \mathrm{dL}$ respectively and in hyperglycemic individuals consuming the treatment, pooled means were 126.18 \pm 8.63 , $42.37 \pm 1.57,137.58 \pm 8.75$ and $175.07 \pm 11.47$ respectively. Pooled means for the effect of intervals on lipid profile of both normal and hyperglycemic individuals are represented in Table 3. Low density lipoproteins level in study 1 at day 0 were observed as 
$103.77 \pm 6.28$ which dropped to $98.93 \pm 9.83$ after 30 days and in study 2 , it dropped from $132.77 \pm 4.83$ to $126.1 \pm 11.12 \mathrm{mg} / \mathrm{dL}$ after 30 days. High density lipoproteins levels raised in normal subjects from $40.83 \pm 3.29$ to $40.95 \pm 3.91 \mathrm{mg} / \mathrm{dL}$ and in hyperglycemic subjects from $40.75 \pm 1.90$ to $42.95 \pm 1.63 \mathrm{mg} / \mathrm{dL}$ in 30 days. Levels of triglycerides and total cholesterol in normal study dropped from $121.55 \pm 7.39$ to $108.23 \pm 8.15 \mathrm{mg} / \mathrm{dL}$ and $166.3 \pm 10.61$ to $148.1 \pm 16.67 \mathrm{mg} / \mathrm{dL}$ respectively after 30 days. In hyperglycemic individuals the level of triglycerides and total cholesterol also lowered from $147.56 \pm 5.83$ to $142.35 \pm 15.43$ and from $188.88 \pm 6.94$ to $168.85 \pm 7.03 \mathrm{mg} / \mathrm{dL}$ respectively after 30 days.

Table 2: Pooled means for effect of treatments on lipid profile of normal and hyperglycemic subjects.

\begin{tabular}{|c|c|c|c|c|}
\hline Treatments & $\begin{array}{c}\text { Low Density Lipoproteins } \\
\text { (mg/dL) }\end{array}$ & $\begin{array}{c}\text { High Density Lipoproteins } \\
(\mathbf{m g} / \mathbf{d L})\end{array}$ & $\begin{array}{c}\text { Triglycerides } \\
\text { (mg/dL) }\end{array}$ & $\begin{array}{c}\text { Total Cholesterol } \\
(\mathbf{m g} / \mathbf{d L})\end{array}$ \\
\hline $\mathrm{N}_{0}$ & $105.65 \pm 6.55^{\mathrm{a}}$ & $38.35 \pm 2.31^{\mathrm{b}}$ & $116.79 \pm 7.66^{\mathrm{a}}$ & $165.75 \pm 10.43^{\mathrm{a}}$ \\
$\mathrm{N}_{1}$ & $98.94 \pm 8.17^{\mathrm{b}}$ & $43.16 \pm 2.64^{\mathrm{a}}$ & $111.03 \pm 10.71^{\mathrm{b}}$ & $146.34 \pm 15.1^{\mathrm{b}}$ \\
\hline $\mathrm{H}_{0}$ & $134.51 \pm 5.08^{\mathrm{a}}$ & $41.27 \pm 2.20^{\mathrm{b}}$ & $153.47 \pm 6.2^{\mathrm{a}}$ & $178.74 \pm 10.33^{\mathrm{a}}$ \\
$\mathrm{H}_{1}$ & $126.18 \pm 8.63^{\mathrm{b}}$ & $42.37 \pm 1.57^{\mathrm{a}}$ & $137.58 \pm 8.75^{\mathrm{b}}$ & $175.07 \pm 11.47^{\mathrm{b}}$ \\
\hline
\end{tabular}

Table 3: Pooled Means for Effect of Intervals on Lipid Profile of Normal and Hyperglycemic Subjects.

\begin{tabular}{|c|c|c|c|c|c|}
\hline Studies & Intervals & $\begin{array}{c}\text { Low Density } \\
\text { Lipoproteins (mg/dL) }\end{array}$ & $\begin{array}{c}\text { High Density } \\
\text { Lipoproteins }(\mathrm{mg} / \mathrm{dL})\end{array}$ & Triglycerides (mg/dL) & $\begin{array}{l}\text { Total Cholesterol } \\
\text { (mg/dL) }\end{array}$ \\
\hline \multirow{3}{*}{$\begin{array}{c}\text { Normal subjects } \\
\text { (Study I) }\end{array}$} & 0 & $103.77 \pm 6.28^{\mathrm{a}}$ & $40.83 \pm 3.29$ & $121.55 \pm 7.39^{a}$ & $166.3 \pm 10.61^{a}$ \\
\hline & 15 & $104.17 \pm 7.00^{\mathrm{a}}$ & $40.49 \pm 3.28$ & $111.95 \pm 8.38^{\mathrm{b}}$ & $153.73 \pm 15.44^{\mathrm{b}}$ \\
\hline & 30 & $98.93 \pm 9.83^{b}$ & $40.95 \pm 3.91$ & $108.23 \pm 8.15^{\mathrm{b}}$ & $148.1 \pm 16.67^{\mathrm{b}}$ \\
\hline \multirow{3}{*}{$\begin{array}{c}\text { Hyperglycemic } \\
\text { subjects } \\
\text { (Study II) }\end{array}$} & 0 & $132.77 \pm 4.83^{\mathrm{a}}$ & $40.75 \pm 1.90^{c}$ & $147.56 \pm 5.83^{\mathrm{a}}$ & $188.88 \pm 6.94^{\mathrm{a}}$ \\
\hline & 15 & $132.16 \pm 5.68^{\mathrm{a}}$ & $41.75 \pm 1.81^{b}$ & $146.66 \pm 9.32^{\mathrm{a}}$ & $172.97 \pm 6.39^{b}$ \\
\hline & 30 & $126.1 \pm 11.12^{\mathrm{b}}$ & $42.95 \pm 1.63^{\mathrm{a}}$ & $142.35 \pm 15.43^{\mathrm{b}}$ & $168.85 \pm 7.03^{b}$ \\
\hline
\end{tabular}

In Table 4, the mean values for low density lipoprotein in study 1 (normal subjects) were enhanced from 103.21 \pm 6.39 (0 days) to $106.53 \pm 6.59$ (30 days) $\mathrm{mg} / \mathrm{dL}$ in N0 whereas consumption of selected composite flour chapatti group (N1) significantly lowered the LDL level from $104.33 \pm 6.46$ to $91.33 \pm 5.65 \mathrm{mg} / \mathrm{dL}$ in same intervals. Similarly, values for high density lipoprotein levels were recorded as $38.70 \pm 2.40,38.35 \pm 2.38,38.00 \pm 2.36 \mathrm{mg} /$ $\mathrm{dL}$ on 0,15 and 30 days intervals respectively in normal subjects of control group whilst consumption of selected composite flour chapatti group (N1) exhibited significant increment in high density

Table 4: Lipid Profile of Normal and Hyperglycemic Individuals Treated with Composite Flour Chapatti.

\begin{tabular}{|c|c|c|c|c|c|c|}
\hline Studies & Groups & Intervals & $\begin{array}{c}\text { Low Density } \\
\text { Lipoproteins }(\mathrm{mg} / \mathrm{dL})\end{array}$ & $\begin{array}{c}\text { High Density } \\
\text { Lipoproteins }(\mathrm{mg} / \mathrm{dL})\end{array}$ & $\begin{array}{l}\text { Triglycerides } \\
\text { (mg/dL) }\end{array}$ & $\begin{array}{c}\text { Total Cholesterol } \\
(\mathrm{mg} / \mathrm{dL})\end{array}$ \\
\hline \multirow{6}{*}{$\begin{array}{c}\text { Normal } \\
\text { subjects (Study } \\
1 \text { ) }\end{array}$} & \multirow{3}{*}{$\mathrm{N}_{0}$} & 0 & $103.21 \pm 6.39^{\mathrm{ab}}$ & $38.70 \pm 2.40$ & $120.6 \pm 7.46^{\mathrm{a}}$ & $169.7 \pm 10.5$ \\
\hline & & 15 & $107.19 \pm 6.63^{\mathrm{a}}$ & $38.35 \pm 2.38$ & $116.79 \pm 7.23^{\mathrm{ab}}$ & $165.75 \pm 10.26$ \\
\hline & & 30 & $106.53 \pm 6.59^{\mathrm{ab}}$ & $38.00 \pm 2.36$ & $112.98 \pm 6.99^{\mathrm{bc}}$ & $161.8 \pm 10.01$ \\
\hline & \multirow{3}{*}{$\mathrm{N}_{1}$} & 0 & $104.33 \pm 6.46^{\mathrm{ab}}$ & $42.95 \pm 2.66$ & $122.5 \pm 7.58^{\mathrm{a}}$ & $162.9 \pm 10.08^{\mathrm{a}}$ \\
\hline & & 15 & $101.15 \pm 6.26^{b}$ & $42.62 \pm 2.64$ & $107.1 \pm 6.63^{\mathrm{cd}}$ & $141.7 \pm 8.77^{b}$ \\
\hline & & 30 & $91.33 \pm 5.65^{c}$ & $43.90 \pm 2.72$ & $103.47 \pm 6.4^{\mathrm{b}}$ & $134.4 \pm 8.32^{\mathrm{b}}$ \\
\hline \multirow{6}{*}{$\begin{array}{l}\text { Hyperglycemic } \\
\text { Subjects (Study } \\
\text { 2) }\end{array}$} & \multirow{3}{*}{$\mathrm{H}_{0}$} & 0 & $132.44 \pm 4.94^{\mathrm{ab}}$ & $39.60 \pm 1.48^{\mathrm{d}}$ & $149.8 \pm 5.59^{\mathrm{bc}}$ & $189.9 \pm 7.08^{a}$ \\
\hline & & 15 & $135.11 \pm 5.04^{\mathrm{a}}$ & $40.80 \pm 1.53^{\mathrm{cd}}$ & $154.1 \pm 5.75^{\mathrm{ab}}$ & $174.1 \pm 6.49^{b}$ \\
\hline & & 30 & $135.97 \pm 5.07^{\mathrm{a}}$ & $43.40 \pm 1.62^{\mathrm{a}}$ & $156.5 \pm 5.84^{a}$ & $172.2 \pm 6.42^{\mathrm{b}}$ \\
\hline & \multirow{3}{*}{$\mathrm{H}_{1}$} & 0 & $133.1 \pm 4.97^{\mathrm{ab}}$ & $41.90 \pm 1.57^{\mathrm{bc}}$ & $145.32 \pm 5.42^{\mathrm{c}}$ & $187.86 \pm 7.01^{\mathrm{a}}$ \\
\hline & & 15 & $129.2 \pm 4.82^{b}$ & $42.70 \pm 1.60^{\mathrm{ab}}$ & $139.21 \pm 5.19^{d}$ & $171.84 \pm 6.41^{\mathrm{b}}$ \\
\hline & & 30 & $116.23 \pm 4.34^{c}$ & $42.50 \pm 1.59^{\mathrm{ab}}$ & $128.19 \pm 4.78^{\mathrm{e}}$ & $165.5 \pm 6.17^{c}$ \\
\hline
\end{tabular}

lipoprotein concentrations from $42.95 \pm 2.66$ to $43.90 \pm 2.72 \mathrm{mg} / \mathrm{dL}$. Likewise, momentous enhancement was reported in hyperglycemic subjects of $\mathrm{H} 0$ and $\mathrm{H} 1$ groups from $39.60 \pm 1.48$ to $43.40 \pm 1.62 \mathrm{mg} /$ $\mathrm{dL}$ and $41.90 \pm 1.57$ to $42.50 \pm 1.59 \mathrm{mg} / \mathrm{dL}$, accordingly. Moreover, mean values for triglycerides concentrations of control group (N0) of normal subjects were recorded as $120.6 \pm 7.46,116.79 \pm 7.23$, and $112.98 \pm 6.99 \mathrm{mg} / \mathrm{dL}$ whereas $122.5 \pm 7.58,107.1 \pm 6.63 \mathrm{mg} / \mathrm{dL}$ and $103.47 \pm 6.4$ on 0,15 and 30 days respectively after consuming selected composite flour chapatti group (N1). 
Similarly, significant enhancement was observed in triglycerides levels in control group (H0) from $149.8 \pm 5.59$ to $156.5 \pm 5.84 \mathrm{mg} / \mathrm{dL}$ and momentous reduction was observed after consuming selected composite flour chapatti group (H1) from $145.32 \pm 5.42$ to $128.19 \pm 4.78 \mathrm{mg} / \mathrm{dL}$. Likewise, mean values of total cholesterol in normal subjects of group (N0) showed $169.7 \pm 10.5$ $\mathrm{mg} / \mathrm{dL}$ at day 0 which reduced to161.8 \pm 10.01 after 30 days. The subjects consuming treatment showed reduction from $162.9 \pm 10.08$ to $134.4 \pm 8.32 \mathrm{mg} / \mathrm{dL}$ after 30 days whereas the hyperglycemic individuals consuming the treatment showed reduction in total cholesterol from $187.86 \pm 7.01$ to $165.5 \pm 6.17 \mathrm{mg} / \mathrm{dL}$ within 30 days' time interval whereas reduction of total cholesterol in the control hyperglycemic group showed reduction from $189.9 \pm 7.08$ to $172.2 \pm 6.42 \mathrm{mg} / \mathrm{dL}$ in the same time period (Table 4 ).

\section{Discussion}

The composite flour preparing by lentils, chickpea and guargum exhibited significant hypocholesterolemic effect in male Sprague Dawley rats for 8 weeks. They observed that consumption of composite flour enriched with $3 \mathrm{~g} / 100$ g guar gum showed lowest cholesterol levels $(82.46 \mathrm{mg} / \mathrm{dl})$ and caused significant reduction $(17.2 \%)$ in comparison with control. Whilst, low density lipoprotein and triglycerides concentrations were recorded as $29.7 \%$ and $28.4 \%$ in comparison to control, accordingly. They concluded that presence of dietary fibers mainly lowered the levels of cholesterol, low density lipoproteins, and triglycerides. Following mechanisms are involved in hypocholesterolemic potential of composite flour such as suppression of LDL-C oxidation, proliferation of aortic smooth muscle cells, and maintenance of the physical properties of arterial walls, respectively. They are good source of ferulic, and p-coumaric acids polyphenols to lower lipid levels in experimental subjects $[15,16]$. In another study conducted by Crujeiras and their co-workers [15], they determined that administration of chickpeabased pulse diet-fed diet significantly lowered the total cholesterol from 215 to $182 \mathrm{mg} / \mathrm{dl}$ in experimental subjects [15]. Fiber from chickpea flour exerts hypocholesterolaemic effect via suppressing the synthesis of fatty acids in the liver through fiber fermentation products such as propionate, butyrate, and acetate.

These short chain fatty acids suppress the cholesterol and fatty acid biosynthesis through suppressing the acetate (provides acetyl-CoA) utilization [17]. Moreover, in another study reported that supplementation of chickpea diet to healthy male 'SpragueDawley' rats and showed significant reductions in low density lipoproteins, triglycerides, and enhancement in high density lipoproteins [18]. Likewise, diets enriched peas (46-62\%) and chickpea (49-65.4\%) supplemented to Sprague-Dawley' rats and lowered the levels of plasma cholesterol [19]. The current results are in harmony with the investigations of Rabey et al. [20], they found that supplementation of oat and barley bran are involved to lower the induced hyperlipidemia and hypercholesterolemia in the experimental subjects (male albino rats). They categorized into different four groups each comprised of five rats such as Control
(G0), G2 (1.0\% cholesterol), G2 (10\% oat bran, $1 \%$ cholesterol), and G3 (10\% barley bran, $1 \%$ cholesterol), respectively.

Administration of cholesterol to experimental animals caused significant increment in concentrations of total cholesterol, low density lipoprotein, very low-density lipoprotein, and triglycerides and decreased the levels of high-density lipoproteins. The supplementation of bran and barley significantly lowered the concentrations of tri glycerides, cholesterol, very low-density lipoproteins, and increased the levels of high-density lipoproteins. Conclusively, oat bran and barley bran have been found more effectual to prevent from the hypercholesterolemia complications as compared to control [20]. In hypercholesterolemic male Wistar rats, chickpea flour significantly lowered the total cholesterol, triglycerides, low density lipoproteins and enhanced high-density lipoproteins in the liver. In another study, the administration of chickpea and wheat flour chapattis significantly showed reductions in (serum total cholesterol of $0.25 \mathrm{mmol} / \mathrm{L}$ (p 0.01) and low-density lipoprotein-concentrations $(0.20 \mathrm{mmol} / \mathrm{L})$. In addition, prepared chapattis also increased the polyunsaturated fatty acids and decreased the monounsaturated fatty acids [21].

Different concentrations of wheat and soy flour (90:10, 80:20, 70:30, and 60:40) supplemented to Wistar rats for 28 days evaluated for biochemical analysis. They found that prepared bread (wheat flour (90\%), soy flour (10\%)) lowered the markers (low density lipoprotein, cholesterol and triacyl glycerol levels) (Table 2) as compared to the control [22]. Similarly, in another study, wheat and finger millet flour administration to human has been reported to lower the concentrations of cholesterol, triglycerides, low density lipoproteins, and very low-density lipoproteins as well as also enhanced the levels of high-density lipoproteins, respectively. In conclusion, flour has been found significant hypoglycemic agent in human and experimental animals [23]. The previous investigations of Yang and their colleagues, they found that chickpea flour has significant effect on visceral adiposity, dyslipidemia and insulin resistance of experimental volunteers. Experimental subjects were divided into three groups including control group, high fat supplemented diet group, and high fat plus chickpea flour enriched group for 8 months.

They investigated that high fat administrated rats $(0 \cdot 032 \pm$ $0.004 \mathrm{~g} / \mathrm{g}$ ) showed higher epididymal fat pad weight $\mathrm{v}$. total body weight as compared to control fed diet rats $(0 \cdot 015 \pm 0 \cdot 006 \mathrm{~g} / \mathrm{g})$ and smaller in high fat plus chickpea flour supplemented rats $(0 \cdot 023 \pm 0 \cdot 007 \mathrm{~g} / \mathrm{g})$, accordingly. Chickpea flour also showed reduction in levels of triglycerides, cholesterol, low density lipoproteins, very low-density lipoproteins and enhancement in levels of high-density lipoproteins, respectively. In muscle and liver, rats induced high fat diet have higher concentration of triacylglycerol (TAG) whereas supplementation of chickpea flour drastically decreased the levels of TAG as muscle, $39 \%$; liver, $23 \%$, respectively. Likewise, the enhancement in lipoprotein lipase (LPL) activity in hepatic TAG lipase and epididymal adipose tissue in liver 
observed as 23 and $40 \%$ whereas chickpea supplementation to rats were normalized these levels. In addition, chickpea flour also showed reduction in leptin and LPL mRNA content in epididymal adipose tissue [24]. In hypercholesterolemic postmenopausal women, supplementation of soy protein contained $150 \mathrm{~g}$ isoflavones for 10 weeks prevented from the cardiovascular disorders through decreasing the concentrations of low-density lipoproteins, triglycerides, cholesterol and showed high density lipoproteins \& paraoxonase activity increment [25].

The earlier findings of Jenkin and their colleagues, they explicated that high based diet from wheat has been found effective in hyperlipidemic men and women. They found that high protein diet administrated to hyperlipidemic men and women and caused significant reductions in serum LDL oxidation, triglycerides, cholesterol and enhancement in high density lipoproteins, respectively. In addition, high consumption of fruits and vegetables are significant linked with prevention from the cardiovascular risks [26].

\section{Conclusion}

Cereals are promising source of bioactive compounds such as dietary fibers, ferulic acid, coumaric acid, and phytonutrients. These compounds have been found as chemo-preventive agent against various human maladies such as cancer insurance, diabetes complications, cardiovascular disorders, obesity, and oxidative stress. Composite flour is due to the presence of glucan that prevent from the hypercholesterolemia through lowering the low-density lipoprotein, triglycerides, and enhancing the concentrations of high-density lipoprotein.

\section{Conflict of Interest}

There is no conflict of interest among authors.

\section{References}

1. Bender DA, Bender AE (2014) Benders' Dictionary of Nutrition and Food Technology. 12th (Edn). Woodhead Publishing, Abington, USA.

2. (2016) FAO (Food and Agriculture Organization of the United Nations). International Fund for Agriculture Development (IFAD). The State of Food Insecurity in the World: The Multiple Dimension of Food Security. Rome.

3. Oluwakemi OA, Omodele I (2015) The Current Status of Cereal (Maize Rice and Sorghum) Crops Cultivation in Africa: Need for Integration of Advances in Transgenic for Sustainable Crop Production. International Journal of Agricultural Policy and Research 3(3): 133-145.

4. Bader Ul Ain H Saeed F, Ahmad N, Imran A, Niaz B, Afzaal M et al. (2018) Functional and health-endorsing properties of wheat and barley cell wall's non-starch polysaccharides. International Journal of Food Properties 21(1): 1463-80.

5. Freeland KR, Anderson GH, Wolever TMS (2009) Acute effects of dietary fibre and glycaemic carbohydrate on appetite and food intake in healthy males. Appetite 52(1): 58-64.

6. Behall KM, Scholfield DJ, Hallfrisch J (2004) Lipids significantly reduced by diets containing barley in moderately hypercholesterolemic men. J Am Coll Nutr 23(1): 55-62.

7. Shimizu C, Kihara M, Aoe S, Araki S, Ito K, et al. (2008) Effect of high $\beta$-glucan barley on serum cholesterol concentrations and visceral fat area in Japanese me a randomized, double- blinded, placebo-controlled trial. Plant Foods Hum Nutr 63(1): 21-25.

8. Malkki Y, Cho SS, Dreher ML (2001) Handbook of Dietary Fiber. Oat fiber: production, composition, physicochemical properties, physiological effects, safety, and food applications 497-517.

9. Duru KC, Kovaleva EG, Danilova IG, Van der Bijl P, Belousova AV (2018) The potential beneficial role of isoflavones in type 2 diabetes mellitus. Nutr Res 59: 1-15

10. Yang Y, Zhou L, Gu Y, Zhang Y, Tang J (2007) Dietary chickpeas reverse visceral adiposity, dyslipidemia and insulin resistance in rats induced by a chronic high-fat diet. Br J Nutr 98(4): 720-726.

11. Mani I, Mani (1987) UV: Effect of wheat bran supplementation on blood sugar, glycosylated protein and serum lipids in NIDDM subjects. Plant Foods for Human Nutrition 37:161-168.

12. Kim JI, JK Paik, OY Kim, HW Park, JH Lee, et al. (2011) Effects of lycopene supplementation on oxidative stress and markers of end othelial function in healthy men. Atherosclerosis 215(1): 189-195

13. Alshatwi AA, MA Al Obaaid, SA Al Sedairy, AH Al Assaf, JJ Zhang, KY Lei (2010) Tomato powder is more protective than lycopene supplement against lipid peroxidation in rats. J Nutr Res 30(1): 66-73.

14. Steel RGD, JH Torrie, D Dickey (1997) Principles and procedures of statistics: a biometrical approach, $3^{\text {rd }}(\mathrm{Edn})$. Mc Graw Hill Book Co, Inc, New York.

15. Tikkanen MJ, Adlercreutz H (2000) Dietary soy-derived isoflavone phytoestrogens: could they have a role in coronary heart disease prevention. Biochem Pharmacol 60(1): 1-5.

16. Pan W, Ikeda K, Takebe M (2001) Genistein, daidzein and glycitein inhibit growth and DNA synthesis of aortic smooth muscle cells from strokeprone spontaneously hypertensive rats. J Nutr 131(4): 1154-1158.

17. Crujeiras AB, Parra D, Abete I (2007) A hypocaloric diet enriched in legumes specifically mitigates lipid peroxidation in obese subjects. Free Radic Res 41(4): 498-506.

18. Wright RS, Anderson JW (1990) Propionate inhibits hepatocyte lipid synthesis. Proc Soc Exp Biol Med 195(1): 26-29.

19. Yang Y, Zhou L, Gu Y (2007) Dietary chickpea reverse visceral adiposity, dyslipidaemia and insulin resistance in rats induced by a chronic highfat diet. Br J Nutr 98(4): 720-726.

20. El Rabey HA, Al Seeni MN, Amer HM (2013) Efficiency of barley bran and oat bran in ameliorating blood lipid profile and the adverse histological changes in hypercholesterolemic male rats. Biomed Research International p. 10

21. Amaral AL Ferreira, ES Neves, VA Demonte A (2014) Legumin from chickpea: hypolipidemic effect in the liver of hypercholesterolemic rats. Nutrition \& Food Science 44(5): 378-388

22. Ebuehi OA, Okafor HK (2015) Defatted Soy Flour Supplementation of Wheat Bread ameliorates Blood Chemistry and Oxidative Stress in Wistar rats. Nig Q J Hosp Med 5(3): 156-163.

23. Teradal D, Joshi N, Aladakatti RH (2017) Therapeutic evaluation of grain based functional food formulation in a geriatric animal model. Journal of Food Science and Technology 54(9): 2789-2796.

24. Yang Y, Zhou L, Gu Y, Zhang Y, Tang J et al. (2007) Dietary chickpea reverse visceral adiposity, dyslipidaemia and insulin resistance in rats induced by a chronic high-fat diet. Br J Nutr 98(4): 720-726.

25. Kimiagar M, Mehrabi Y, Esmaillzadeh A, Hu FB, Willett WC et al (2007) Dietary soya intake alters plasma antioxidant status and lipid peroxidation in postmenopausal women with the metabolic syndrome. British Journal of Nutrition 98(4): 807-813.

26. Jenkins DJ, Kendall CW, Vidgen E, Augustin LS, Van Erk M, et al. (2001) High-protein diets in hyperlipidemia: effect of wheat gluten on serum lipids, uric acid, and renal function. Am J Clin Nutr 74(1): 57-63. 


\section{ISSN: 2574-1241}

DOI: 10.26717/BJSTR.2019.19.003265

Muhammad Hanif Mughal. Biomed J Sci \& Tech Res

(c) (9) This work is licensed under Creative Commons Attribution 4.0 License

Submission Link: https://biomedres.us/submit-manuscript.php

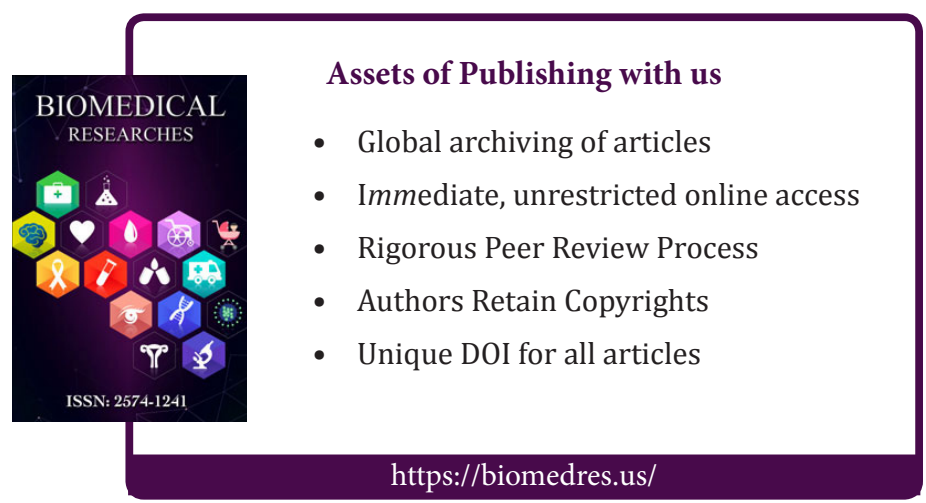

